\title{
STRESS FACTORS, EFFECTS AND MANAGEMENT TECHNIQUES AMONG INTERNATIONAL STUDENTS
}

\section{Szerzők:}

Anioke Blessing Nkiruka

University of Debrecen

Szerző e-mail címe:

aniokenkiruka@gmail.com

\section{Lektorok:}

Ferenc Mező (Ph.D.)

Eszterházy Károly Catholic University

Lajos Kelemen (Ph.D.)

Poliforma Bt.

...és további két anonim lektor

\section{Absztrakt \\ STRESSZ TÉNYEZŐK, -HATÁSOK ÉS -KEZELÉSI TECHNIKÁK NEMZETKÖZI HALLGATÓK KÖZÖTT}

Jelen tanulmány egy nem kísérleti jellegű, leíró, kvantitatív kutatás tapasztalatait mutatja be. A kutatás célja nemzetközi hallgatói közösség $(n=374)$ stresszszintjének felmérése volt. Az adatelemzés módszereként egyszerú lineáris és többszörös regressziót került alkalmazásra. Az eredmények azt mutatták, hogy a nemzetközi hallgatók jelentős személyes, tanulmányi, pszichológiai és enyhe környezeti stressztényezőket tapasztalnak mindennapi életük során.

Kulcsszavak: Stressz tényezők, stresszhatások, stresszkezelési technikák, nemzetközi hallgatók

Diszciplínák: orvostudomány, pszichológia

\section{Abstract}

The present study shows experiences of a non-experimental, descriptive, quantitative research. The objective of this research was used to assess the level of stress among international students $(n=374)$. Simple linear and multiple regression was used as the method of data analysis. The results revealed that international students experience significant personal, academic, psychological, and slight environmental stress factors in their daily life.

Keywords: Stress factors, Stress effects, Stress management techniques, International students

Disciplines: medicine, psychology 
Anioke, Blessing Nkiruka (2021): Stress Factors, Effects and Management Techniques among International Students in the University of Debrecen, Hungary. Lélektan és hadviselés interdiszciplináris folyóirat, III. évf. 2021/2. szám. 77-106. doi: 10.35404/LH.2021.2.77

The occurrence of the pandemic corona virus has caused stress on international students because of hysteria, tension, and fear of contacting the virus. This makes them feel unhappy and insecure, the contact details of psychologists were made available on several online platforms to provide counselling and psychotherapy to help curb the psychological problems.

The World Health Organization has named "Stress" as the "Health Epidemic of the 21st Century" The effect of stress on our emotional and physical health can be devastating. A current study in the USA suggests that more than $50 \%$ of people had decreased productivity at work which was impacted by stress. There was a $10-30 \%$ increase in the levels of stress across all demographic Between 1983 and 2009, Stress levels increased by $10-30 \%$ among all the USA demographic population (FINK, 2017, p. 1). Currently, there are different ways and purposes of using the terminology "stress". We see stress as an experience that is negative because when people say they are stressed, we know the meaning. Psychologists have differentiated between positive stress called "euress" and negative or harmful stress called "distress". In terms of research, the effect of stress now encompasses behavioral, psychological, bio-chemical and physiological effects (KENNARD, 2018).
Stress is composed of a composite process that is triggered by a psychological or physical threat to the homeostasis of the individual consisting of varying responses behaviorally, physiologically and psychologically (BALI and JAGGI, 2015). Though Stress is normally regarded as a response that is negative, it is certainly composed of a major mechanism for ascertaining the survival of individuals. However, stress can become harmful by triggering a response due to stress over and over again without a stimulus that is challenging, or continuous subjection to situations that are challenging. In any of the context mentioned above, documentation reveals that tenacious factor for the cultivation of conditions that are "psycho-pathological" is stress (HARKNESS and HAYDEN, 2018). Stress is a usual part of the lives of individuals on a daily basis. Its consequences differ according to the individual even when faced with the same situation. Some individuals do not feel strained while others so Stress is a normal part of daily life. However, its effects often vary across individuals and despite similar circumstances, some people do not feel under strain while others may be severely affected. Several reasons for this could be because individuals' stimulus response, perception of reality resource recognition for its management differs. When an individual sees a situation like he/she cannot cope with 
it then it is called perceived stress. (HARKNESS et al., 2020; CAVALLO and CARPINELL, 2016).

Stress is evaluated to cost the businesses of America about three hundred billion dollars yearly (FINK, 2017). Managing stress has several benefits including boosting the function of the immune system, energy boosting, giving room for relaxation, improve mood and good energy. International students face a challenge of stress and adjust accordingly (GARZA and GUZMAN, 2015). It is therefore essential to note that low stress does not automatically determine that students will better perform, but as a matter of fact correspondingly, they task would be seen as unchallenging to them and may perceive the task as unchallenging and may simply get them bored. Although, students can perform optimally when pushed by certain stress levels, as long as it is not expertly managed as a result of insufficient stress coping resources, it can lead to negative consequences for both students and the institution (UCHIL, 2017).

\section{Operational Definition of Terms}

1. Contributing factors: These are factors that cause or induce stress. It can also be called stressors.

2. Coping mechanism/ Stress Management Techniques: How international students manage their stress experiences.

3. Stress Effects: The consequences that arose as a result of the stress.
4. International Students: Students who came from 113 countries of the world as listed who currently study in the University of Debrecen.

5. Medical and Health related Faculties: Summation of Faculty of Medicine, Faculty of Dentistry, Faculty of Health, Faculty of Pharmacy and Faculty of Public Health.

6. Science related Faculties: Summation of Faculty of Science and Technology, Faculty of Engineering, Faculty of Economics and Business and Faculty of Agricultural and Food Sciences and Environmental Management.

7. Art related Faculties: Summation of Faculty of Music, Faculty of Informatics, Faculty of Law, Faculty of Child and Adult Education and Faculty of Humanities.

\section{Literature Review}

Concept of Stress. The concept "stress" has a contrary definition for different individuals under dissimilar conditions. The earliest and widespread stress definition was propounded by Selye Hans who said that Stress is the body's response to any form of demand that is not specific. Hans asserted that stress is dissimilar to arousal emotionally or tension in the nerves since stress can happen under or in reaction to an anaesthetic agent in animals and 
man. The term stress that is utilized by Hans Selye has gained acceptance in all international languages. As highlighted by Hans Selye, Stress is not a thing that should be avoided, because in reality there cannot be an avoidance of stress because being alive requires a need for energy that maintains life. Indisputably when a person is sleeping, there must be a continuity of function of his/her respiratory, cardiovascular, digestive, nervous system and other body organs. The expectation of absolute stress freedom can only happen after a person dies. The concept of Selye and his perspective that stress is better considered as a response that is not specific has created so much dispute and argument. As a result of their value heuristically, there will be an additional consideration below. Other detailed review on stress in disease and health is described as follows:

1. "In behavioral sciences, stress is regarded as the perception of threat, with resulting anxiety discomfort, emotional tension, and difficulty in adjustment" (FINK, 2017: 4).

2. "In the group situation, lack of structure or loss of anchor "makes it difficult or impossible for the group to cope with the requirements of the situation, and the problem of leadership and interpersonal behaviour becomes one of evolving or supplying a structure or anchor and of supplying the expertness for coping with the demands of the situation" (FINK, 2017: 4).

3. "Stress can also be defined in terms of pure neuroendocrinology. Eugene Yates, for example, defined stress as any stimulus that will provoke the release of ACTH and adrenal glucocorticoids. Presumably, the same might apply to the equally powerful sympathetic markers of stress, underscored earlier by Walter Cannon" (FINK, 2017: 4).

4. "Selye also mentions Richard Lazarus, famous for his work in cognitive psychology and focus on the emotions. Lazarus underscores the difficulties of reaching a precise overarching definition of stress by setting out the following different meanings of the term: In spite of consistent confusion about the precise meaning of the term, stress is widely recognized as a central problem in human life. Scientists of many disciplines have conceptualized stress but each field appears to have something different in mind concerning its meaning. For the sociologist, it is social disequilibrium, that is, disturbances in the social structure within which people live. Engineers conceive of stress as some external force which produces strain in the materials exposed to it. Physiologists deal with the physical stressors that include a wide range of stimulus conditions that are noxious to the body. In the history of psychological stress research, there has been no clear separation between physical stressors which attack biological tissue systems and psychological stressors which produce their effects purely because of their psychological significance" (FINK, 2017: 4).

5. In their seminal review "The Stressed Hippocampus, synaptic plasticity and lost memories,"

KIM and DIAMOND (2002) suggest a three-component definition of stress that can be applied broadly across species and paradigms. First, stress requires heightened excit- 
ability or arousal, which can be operationally measured using electroencephalography, behavioral (motor) activity or neurochemical (adrenaline, glucocorticoid) levels. Second, the experience must also be perceived as aversive. Third, there is lack of control. Having control over an aversive experience has a profound mitigating influence on how stressful the experience feels. The element of control (and "predictability") is the variable that ultimately determines the magnitude of the stress experience and the susceptibility of the individual to develop stress-induced behavioral and physiological sequelae. Thus, the magnitude of neurocognitive stress (S) approximates to the product of: 1 Excitability/Arousal (E) 1 Perceived aversiveness (A) 1 Uncontrollability (U)" (FINK, 2017: 4).

The ancient people such as Hippocrates and Aristotle were aware of stress factors and the impending consequences. Yet, Bernard Claude was the prime person to officially describe how multiple celled organisms are being protected from stress. Selye Hans propounded the 1st stage of General Adaptation Syndrome which is the global medium of response to stress by organisms and vertebrates. (CAN et al., 2020).

The American Psychological Association identifies 3 types of stress:

1. Acute Stress: short-term, most common, it is body's immediate reaction to a new challenge, event, or demand, and it triggers your fight-or-flight response

2. Episodic- Acute Stress: acute stress happening frequently

3. Chronic stress: Long term, constant stress occurring when acute stress is not resolved and lasts for long periods of time. FRESHWATER S. (2018).

\section{Empirical Review}

Contributing factors (causes) of stress among international students are:

1. Physical Factors. According to KSHIRSAGAR and SEEMA (2016) the causes of stress among undergraduate students includes high rate of competition and tensions from of academic performance, exorbitant cost of education (finance), difficulty in coping, finding or trusting friends (social connections).

2. Academic Factors. The system of education contributes a leading role which in turn results to an increase in the level of stress experienced by students. These includes lecture halls with too many students, wide syllabus, lack of proper facilities and resources, many hours of learning. There are 4 stress dimensions inadequacy of the individual, phobia for failure, inadequate relationship between the teacher and the student, difficulties interpersonally and improper facilities for study (REDDY et al., 2018; YIKEALO, 2018).

Several interventions for managing stress have effect on the performance of students academically and psychologically. Findings revealed that the techniques for managing stress produce higher students' grades. Enhanced performance psychologically and academically reduce stress and improves posing coping (CHINAVEHA, 2010). 
3. Psychological/Mental Health Factors. International students hardly communicate their social concerns and emotions or challenges with their peer group because they only build contact with their course mates in the classroom alone. In view of the fact that language is connected to the culture and society that we live in, language barrier (when people doesn't communicate in identical language), there is absence of relationship creation channelled by communication and social life (RAJAB et. al., 2014; KRONERHERWIG, 2014).

4. Environmental Factors. In a study carried out in the Journal of Economics, Business and Management by RAJAB et. al. (2014) on "Acculturative Stress among International Students". The findings of the study revealed clearly that most of the undergraduate international students witness acculturative stress moderately. The topmost acculturative stress mean dimensions were due to culture shock according to the seven subscales, the findings clearly point to dimension of stress due to change/culture shock. The findings unarguably emphasized that international undergraduates' international students in University of Technology Malaysia came from diverse countries and host community adjustment which is customary in nature might be and rather tricky and hard to understand. The average results demonstrate that it is more challenging for undergraduate students to adjust to host nation's ethnic group which is integrated and more like in University of Technology Malaysia.
Effects/Consequences of Stress among International Students. The result of the study conducted by RAJAB et. al., 2014 also pointed out that homesickness occurs in individuals or students who are not close to their family and environment, so they want to return to the environment they are familiar with as a result of loneliness and differences in culture. These may become worse if the students do not willingly talk about their feelings and emotions with others, which might in turn leads to social isolation from their peer group.

Stress has effect on the physical, psychological and cognitive (such as attention, concentration) life of students which have impact on their success academically (NILANI et al., 2016; PASCOE, 2020).

The effect of stress could be related to health or not related. The effects that are not related to health includes anger, absenteeism, fear, behavioural changes or attitudes, lashing out on colleague, social isolation (distancing self from friends and family) and an impending attempt to fail to finish semesters. The effects related to health includes depression, poor nutrition intake or eating habits and attempts to commit suicide. (SIMPSON, 2018; BEITER et al., 2014).

Coping Mechanism/Stress Management Techniques are:

1. Physical Techniques. RAJAB et. al. (2014) established that it is pertinent for international students to reinforce peer social network because these friendships make room for them to adjust socially and by implication leads to stress reduction. Possessing self- 
determination can help international students to reduce stress levels due to change in culture or culture shock. This can assist them to act and stimulate themselves when they are faced with challenges and pressures from family distance and survival struggle without the usual support at home thereby reducing stress due to change in culture or culture shock in the host environment.

Several interventions exist to reduce stress according to the choices and necessity. (GALBRAITH and BROWN, 2011). The techniques of managing stress includes early practices like Yoga (CHONG et al., 2011) and Tai Chi (http 3) and also physical activities (ASMUNDSON, 2013) are mostly stated are often important in dealing with stress.

The management of stress by Undergraduate students involves figuring out where the stress comes from, avoiding alcohol, smoking and drugs, sleeping more, talking to close relatives, time management, doing exercise, listening to music and maintaining a healthy and variety of diet. (KSHIRSAGAR and SEEMA, 2016; ALHARBIL and SMITH, 2018; BROUGHAM et al., 2009; PIERCEALL and KEIM, 2007).

In a study carried out by CAN et al. (2020) they used the scheme of detection of the level of stress using signals physiologically in addition to an analyser based on the context of physical activity. When a client feels a level of high stress, the system proposes suitable mobile or traditional methods of reducing stress. They went ahead to collate the effects of mobile and traditional methods of alleviating stress on 15 doctoral students during an eight days training. "Smart bands Empatica E4" was used to collect one thousand four hundred and forty signals physiologically

There is a smart device for managing stress which is beneficial. Currently, applications using smart phones such as Sway, Pause, Calm and Heart math have been established for use inside an environment. (CHENG, 2016).

A study conducted by SIMPSON S. (2018) states that stress can be managed by exercise and diet, engagement socially, university and private counselling, taking course on transition orientation, academic and student support services.

2. Cognitive Techniques. There have been confirmed evidence that traditional meditation, mindfulness (SONG, 2015) and cognitive behavioural therapy (ARCH, 2013) are beneficial in the management of stress.

3. Spiritual/Religious Techniques. A research in psychology demonstrated that spirituality value and faith in the management of stress have valuable effect in stress management and adds to the wellbeing of individuals with high stress levels. The research explained that meditation forms, studying religious books and prayer can lead to the activation of the brain centres that leads to coping strategies and entire happiness. (Net1).

4. Psychological Techniques. One effective way of managing stress is Cognitive Behavioral Therapy. This modifies our thoughts towards situations that are stressful, such as 
concentrating on the positive parts of the situation and re-evaluating what might be the likely impact. Other helpful interventions include interpersonal counselling which give individuals the platform to discuss their stress factors and formulate coping mechanisms; and approaches based on mindfulness (Net2).

\section{Theoretical Background}

Below rows summarize Selye's (1956) theory about General Adaptation Syndrome (GAS) of stress, Emotion Theory by LangeJames, theory of Emergency by Bard-Cannon, Emotion Theory by Singer-Schachter, and Cognitive Appraisal Theory of stress by Lazarus and Folkman.

\section{Selye's (1956) General Adaptation Syndrome} (GAS) of stress. The General Adaptation Syndrome theory by Selye makes an analysis of the response of an individual to stress of long term. It is the main factor why stress is the health problems source by altering normal body function (homeostasis) that is necessary for wellbeing. It speeds up the process of aging and subtracts years from life. General health is enhanced by learning relaxation and other stress management techniques. It is divided into 3 major phases (Figure 1):

A. The initial stage of alarm: The reaction of the body to stressor is featured by a response to flight or fight activating the Parasympathetic Nervous System (PNS) releasing hormones such as noradrenaline and adrenaline from the medulla.
Figure 1. Model of General Adaptation Syndrome (GAS) Model. Source: RICE (2018)

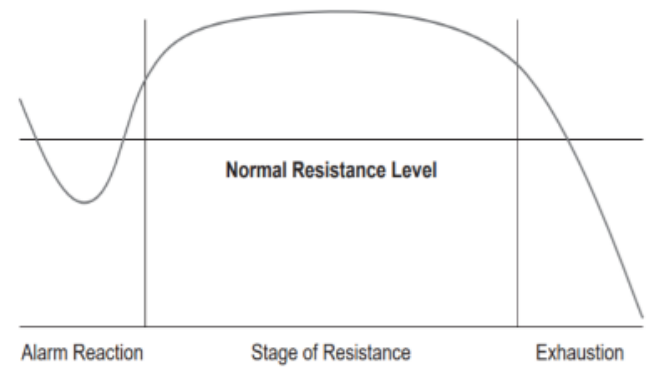

B. The interim stage of resistance: This stage is characterized by an outward appearance. There is an increase in the blood glucose level, adrenaline and cortisol. The individual may be at "action stations" psychologically and physically but may have a calm appearance.

C. The final stage of exhaustion: There is an inhibition of the adrenocorticotrophic hormones which was stimulated already. At this stage, the reserve of energy has been used up and malfunctioning. There is a drop in the level of blood sugar exposing the individual to the vulnerability of death and disease. The final stage creates a reaction that is strong and immediate or excess to low sources of extra stress (SINCERO, 2012). Persistence of a stressor makes an individual's progression through the different stages. Some cases might cause disease or death. Being a stress model, the GAS is primarily concerned with the response of the body to physiological stress. It does not consider other factors that enhance a person's stress response like their feelings, thoughts and how these mental and cognitive factors affect the stress experience. 
Nevertheless, the GAS was a model of high influence producing a lot for additional studies (SINCERO, 2012).

Figure 2 explains that stress is seen as a stimulus and an important event of life that requires adaptation, adjustment, and response. A stimulus such as social content, physical and mental challenges is processed as either a threat or non-threat (No stress). The threat comes from a known or unknown source that provokes a low, thwarted or high- cost response. An unknown source of stress, thwarted or high-cost response leads to anxiety, aggression, and taking risks and can predispose the individual to self-damaging behavior. All these lead to a response biologically (reactivity- i.e. difference in the propensity of response in addition to a genetic constituent, gender, and the history of development). These could create stress mediators, effectors, and outcomes of diseases.

Figure 2. Response-Oriented Stress. Source: RICE (2018)

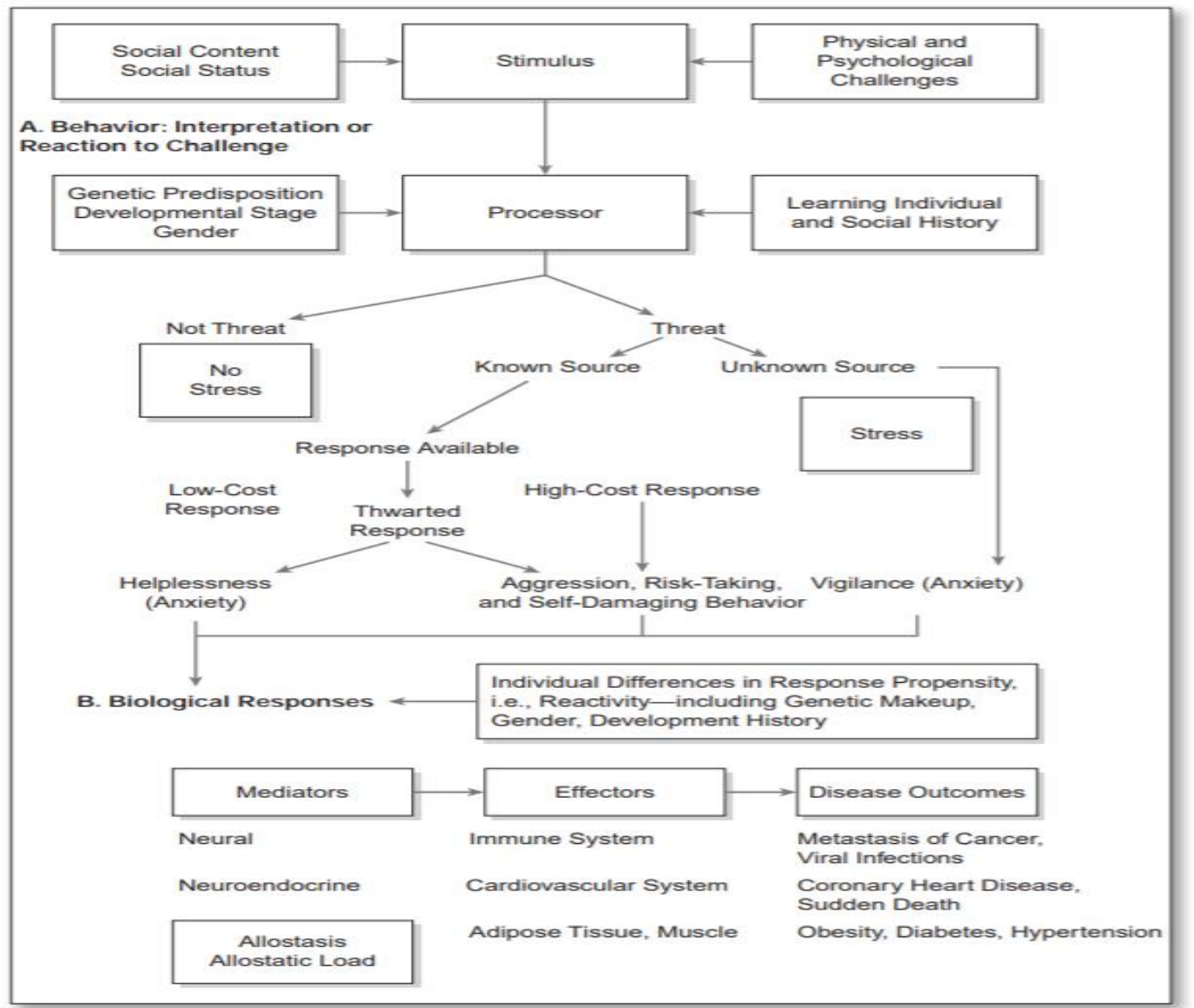


2. Emotion Theory by Lange-James. This theory is on emotion and stress correlation. It was proposed differently by James William and Lange Carl. However, their ideas were unified based on this correlation - emotions is not an instant succession to the recognition of the stress factors or the event that is stressful. They only appear after the stress response of the body. For example, when a person sees a dog that is growling, there is a racing of his/her heart, fast breath and wide opening of the eyes. According to the theorists, the apprehension of fear and other emotion commences only after the person undergo these changes in the body. This implies that the behaviour of emotions is impossible to happen except it is attached to the person's brain (SINCERO, 2012).

\section{Theory of Emergency by Bard-Cannon. This} theory is the reverse of the theory proposed by Lange and James. Based on the theorist Cannon Walter, stress emotional response occurs even when the changes in the body are absent. Cannon mentioned that the brain gradually identifies the body's physiological internal response or visceral when compared with its emotional release response function. The theory was proven by him by the creation of cats that are decorticated, the body's neural relationships are differentiated from the cats' brain cortex. When exposed to a response that is stressful, the cats that are decorticated displayed a behaviour that is emotional which signified rage and offensive feelings. Alterations in the body like teeth baring, erect and growling hair were the emotional manifestations. To buttress further the theory propounded by Canon, Bard Philip broadened Cannon's ideals with an argument that a structure of the brain stem that is lower known as the thalamus is significant in development of responses emotionally. Bard declared that response to emotions is first released which is then sent by the thalamus as signals to the cortex of the brain to interpret it. In addition to this, stress response physiologically begins when signals are sent to the Sympathetic Nervous System (SNS). Finally, the argument of the theory is that stress response emotionally has no significant effect on the response; instead they occur at the same time (SINCERO, 2012).

\section{Emotion Theory by Singer-Schachter. There} was an argument between 2 theorists Schachter Stanley and Singer Jerome that identifying the appropriate emotion demands both the activity of our cognition and our arousal emotionally for us to experience our emotion. The mechanism through which the brain can recognize the stimulus of stress (attribution) to produce an emotion. This theory clearly points out that we are made aware of main factor behind the response emotionally, and when there is no obvious reason, we begin to search for the clues in the environment for the appropriate interpretation of the emotion to happen (SINCERO, 2012).

\section{Cognitive Appraisal Theory of stress by Lazarus} and Folkman. In contrast to the stress model of General Adaptation Model Syndrome, the theory of cognitive appraisal emphasizes the cognition of a person to the stressor which 
creates a response emotionally. It is an emotional theory that involves the people's interpretation of an event personally in assessing their reactions to an emotion. The mode of interpretation of the stressor is important and as stated by Lazarus and Folkman, response to an event that is stressful is by creating an appraisal primarily (Figure 3). During this period, the assessment of the harmfulness of the event is done physically or in relation to esteem, goals, values or core beliefs. The secondary appraisal can occur before, simultaneously or after the first appraisal (primary). In the course of this, there is a consideration to know if the requires re-sources for stress management and the result is affected by the strategies of coping (SINCERO, 2012).

Figure 3: Flowchart transactional theory process of stress and coping according to description by Folkman and Lazarus description. Source: TURNER-COBB and HAWKEN (2019)

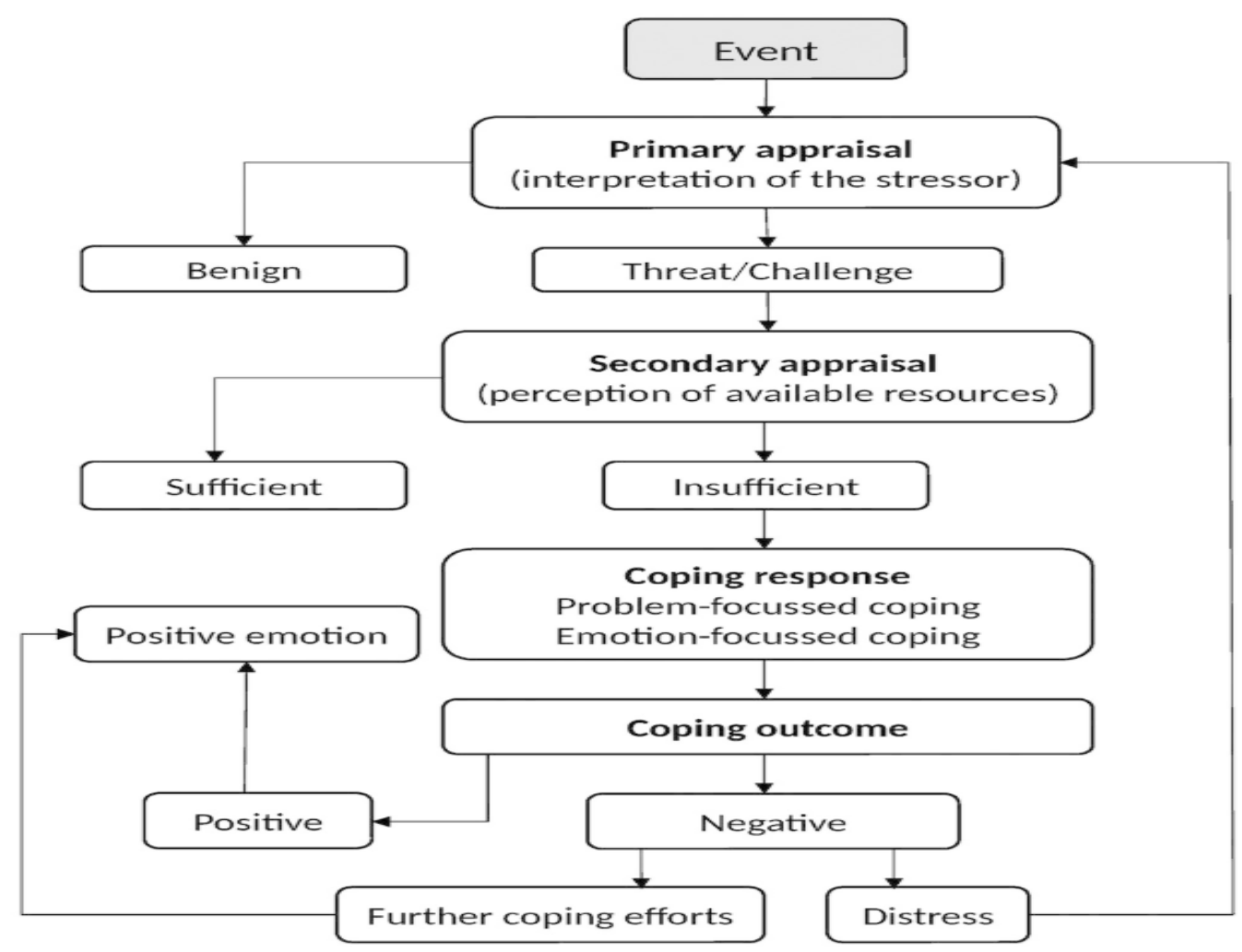




\section{Statement of the Problem}

International students complain largely of stress due to a number of factors expressed by them which leave them in devastating consequences. This has affected their performances academically, socially, psychologically, behaviourally and emotionally. As a result, some international students want to even forfeit their studies. The researcher therefore thought that it is imperative to study the causes of stress on the international students.

\section{Objectives of the Study}

The main objective of the study is to examine the stress factors, effects and management techniques among international students. The specific objectives include:

1. To identify the contributing factors/ causes of stress among international students.

2. To determine the effects/consequences of stress on the physical life of international students.

3. To determine the effects/consequences of stress on the psychological life of international students.

4. To determine the effects/consequences of stress on the behavioural life of international students.

5. To determine the effects/consequences of stress on the Cognitive life of international students.

6. To determine the effects/consequences of stress on the social life of international students.
7. To explore the Stress management techniques employed by the international students.

The justification of the choice of topic, study and objectives is the fact that stress is an inevitable aspect of University students' life which influence their physical, mental, behavioral, cognitive, and social life. As such they should be equipped with the knowledge of stress management techniques.

\section{Research Questions}

On the basis of the above-mentioned literature/references, the research questions are:

1. What are the contributing factors/causes of stress among international students?

2. What are the effects/consequences of stress on the physical life of international students?

3. What are the effects/consequences of stress on the psychological life of international students?

4. What are the effects/consequences of stress on the behavioral life of international students?

5. What are the effects/consequences of stress on the cognitive life of international students?

6. What are the effects/consequences of stress on the social life of international students?

7. What are the stress management techniques employed by international students? 


\section{Research Hypotheses}

H1: Stress has no significant effect on the personal life of international students.

$\mathrm{H} 2$ : Stress has no significant effect on the academic life of international students.

H3: Stress has no significant effect on the psychological life of international students.

H4: Stress has no significant effect on the behavioural life of international students.

H5: Stress has no significant effect on the cognitive life of international students.

H6: Stress has no significant effect on the social life of international students.

H7: Stress management techniques employed by students have no significant effect on stress management among international students.

\section{Theoretical and Practical Significance of the Study}

The findings of this research will be useful to international students, parents, the researcher, institutions, teachers/professional and the society at large to manage stress efficiently. It will be of benefit to them through the following ways:

Students: This study will assist students to first of all comprehend and discover their stressors and will educate them on how to cope with or manage stress. Several techniques will be exposed to them for use in managing their identifies stress factors.

Parents: Will assist in providing social support to their children so as to reduce homesickness due to loneliness.
The researcher: Will have an in-depth knowledge of the study and build her capacity.

The institution: Will utilize designed programmes to support international students emotionally through affection and empathy. In addition, it will also add to the existing body of knowledge.

Teachers/Professionals: Will educate international students on necessary steps to take, contact persons and provision of counselling services to help in stress management.

The society: It will assist them to put modalities in place to reduce the rate of poverty, level of dependency and burden on health care facilities.

Finally, addressing this topic may also potentially lead to the development of further guidelines for stress management and will also provide baseline information for further studies.

Why this Topic is Important for the Health Social Worker? Knowledge obtained from this study and previous competencies of the social worker will enable the Health social worker make accurate assessment, Counselling, group work, Coordination and referral to community services, give social support and teach survivors on how to practice good health behaviours (e.g. Exercise, balanced diet and avoiding smoking and alcohol consumption among others) and Stress management techniques

\section{Sample}

The Study Area was the University of Debrecen (Hungary) in the 2019/2020 academic session. 
This study took place in the University of Debrecen, Hungary in 2019/2020 academic session. Hungary is a Country located in Central Europe with square kilometres of about 93,030 spans. Its border to the North is Slovakia, to the Northeast is Ukraine, to the Southeast and East is Romania, To the South is Serbia, to the Southwest is Croatia and Slovenia and to the West is Austria. Its inhabitants are approximately 10 million. It is an European Union member state with Hungarian as its official Language. The capital and biggest city is Budapest with Debrecen, Gyor, Szeged, Miskolc and Pecs as areas that are majorly urban (Net5).

Debrecen is the 2nd biggest city after Budapest. In the 18th century, it was the biggest city in Hungary with most vital cultural centres for the people of Hungary. It was the Hungarian Capital city in the 1848-1849 revolution and by the second World War end. It houses the University of Debrecen (Net4).

The University of Debrecen (called Debreceni Egyetem in Hungarian) is one of the 34 Universities in Hungary, it is located in Debrecen. It was established in 1538 and since then it is the oldest higher education institute that is operating continuously. It has about $80+$ English language programme that is adequately established for International students, especially in the field of Medicine which first developed English education in 1986. The University of Debrecen, Hungary has a total number of 26938 students, 14 Faculties and 7 campuses.

The total number of international students as of 15 th October 2018 is 5664 (Table 1).
Figure 4: Map of Hungary showing Debrecen. Source: Net7

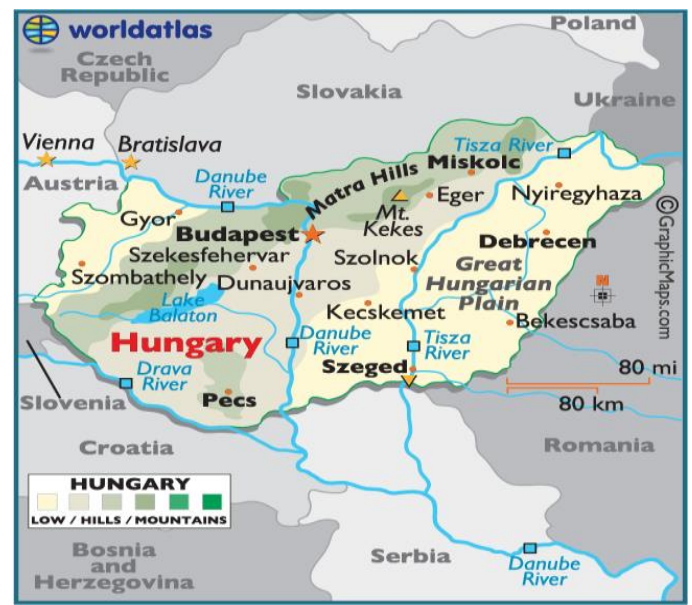

Table 1: The number of International students by Faculties in the University of Debrecen listed on October 15, 2018. Source: Net6

\begin{tabular}{lrrr}
\hline Faculty of... & $\begin{array}{c}\text { Full time } \\
\text { training* }\end{array}$ & $\begin{array}{r}\text { Corres- } \\
\text { pondence } \\
\text { training* }\end{array}$ & Total* \\
\hline Law & 37 & 9 & 46 \\
\hline Medicine & 2081 & 8 & 2089 \\
\hline Humanities & 189 & 5 & 194 \\
\hline Health & 65 & 8 & 73 \\
\hline Dentistry & 376 & 0 & 376 \\
\hline $\begin{array}{l}\text { Economics and } \\
\text { Business }\end{array}$ & 435 & 7 & 442 \\
\hline $\begin{array}{l}\text { Child and } \\
\text { Adult }\end{array}$ & & & \\
Education & 9 & 36 & 45 \\
\hline Pharmacy & & & \\
\hline Informatics & 420 & 9 & 429 \\
\hline $\begin{array}{l}\text { Agricultural } \\
\text { and Food }\end{array}$ & & & \\
$\begin{array}{l}\text { Sciences and } \\
\text { Environmental }\end{array}$ & 152 & 97 & 249 \\
Management & & & \\
\hline Engineering & 678 & 6 & 684 \\
\hline Public Health & 234 & 4 & 238 \\
\hline $\begin{array}{l}\text { Science and } \\
\text { Technology }\end{array}$ & 566 & 4 & 570 \\
\hline $\begin{array}{l}\text { Music } \\
\text { Summary }\end{array}$ & 34 & $\mathbf{1 9 3}$ & $\mathbf{5 6 6 4}$ \\
\hline *person & $\mathbf{5 4 7 1}$ & & \\
\hline
\end{tabular}


These international students came from 113 Countries of the world (Table 2).

Table 2: The number of International students by Continents composed by the researcher from the number of Countries in the University of Debrecen listed on October 15, 2018. Source: Net6

\begin{tabular}{lr}
\hline Continents & Frequency \\
\hline Europe & 1,320 \\
Asia & 2,685 \\
Eurasia & 287 \\
Africa & 1199 \\
North America & 92 \\
South America & 76 \\
Australia & 5 \\
Total & 5664 \\
\hline
\end{tabular}

Out of these 5,664 International students, 5471 are full-time students while 193 are parttime students (Net6). The goal of the University of Deb-recen is service provision in education, health care, research and activities for prevention, agriculture and reinforcing collaboration with business and society to achieve its higher education third mission of spread of culture and sports. There is a continuous improve-ment in the University of Debrecen's position in various rankings of higher education internationally and among the institutions of higher education in Hungary it maintains a role in leading (Net6).

The Population of the Study were International Students from the 14 faculties in the University of Debrecen, Hungary. The study focused on international students and not domestic students because the international students complained of being discriminated by members of the community, culture shocks, loneliness as a result of missing their family, language barrier, financial difficulties due to inability to get good jobs. And if all these factors are not managed properly induces stress and can lead to serious consequences in their physical, psychological, cognitive, behavioural and social life. The international students came from different countries in the various continents of the world.

The Sources of Data used by the researcher was primary data which was gotten directly from the international students consisting of both male and female from different faculties and continents in the University of Debrecen, Hungary.

The Sampling Techniques used in selecting the participants across the 14 faculties in the University was the Probability sampling technique specifically stratified random sampling. Stratified random sampling was used because it increases precision and representativeness of the sample thereby reducing sampling error. The sampling frame used were all the 14 Faculties international students. The researcher divided the strata by related faculties because it is important to the response. The researcher classified the 14 Faculties into Medical and Health related Faculties (Summation of Faculty of Medicine, Faculty of Dentistry, Faculty of Health, Faculty of Pharmacy and Faculty of Public Health) who were 2971 in number. Science related Faculties (Summation of Faculty of Science and Technology, Faculty of Engineering, Faculty of Economics and Business and Faculty of Agricultural and Food Sciences and Environ- 
mental Management) who were 1945 in number and Art related Faculties (Summation of Faculty of Music, Faculty of Informatics, Faculty of Law, Faculty of Child and Adult Education and Faculty of Humanities) who were 748 in number. Hence, the sample size of each related Faculties was calculated as a ratio of the total population.

Using the Slovin's formula developed since 1960 the required

$$
\text { Total Sample Size }(n)=N \div I \text {, }
$$

where

$$
\left.I=1+N(e)^{2}\right),
$$

therefore,

$$
n=N \div\left(1+N e^{2}\right)
$$

International Students.

Where:

$I=$ selection interval

$n=$ sample size,

$N=$ Total Population (i.e. total number of International Students in the University of Debrecen) and

$e=$ Error tolerance used $(95 \%$ confidence level was used which gave a margin error of 0.05 obtained by subtracting the confidence level from 1). This signifies that there are 95 in 100 chances (or .95 in 1) that the results of the sample represent the population's true condition within specific range of precision against 5 in 100 chances 100 (or .05 in 1) that it doesn't.

$1=$ unity (constant). (RONO, 2018).

The researcher plugged the figures in the formula as follows:

$$
\begin{aligned}
& n=5,664 \div\left(1+5,664(0.05)^{2}\right) \\
& n=5,664 \div(1+5,664 \times 0.05 \times 0.05)
\end{aligned}
$$

$$
\begin{aligned}
& n=5,664 \div(1+5,664 \times 0.0025) \\
& n=5,664 \div(1+14.16) \\
& n=5,664 \div 15.16
\end{aligned}
$$$$
\text { The Total Sample Size }(n)=373.6148 \approx 374
$$

The Strata Sample Sizes were determined by the equation below:

Where:

$$
n_{1}=\left(N_{1} \div N\right) \times n
$$

$n_{1}=$ Sample size for the stratum 1

$N_{1}=$ Total population of stratum 1

$N=$ Total population of all the 3 strata

$n=$ Total sample size

The researcher plugged the figures in the formula as follows (Table3):

Stratum 1 (Medical and Health related Faculties $)=(2971 \div 5664) \times 374 \approx 196$

Stratum 2 (Science related Faculties) = $(1945 \div 5664) \times 374 \approx 129$

Stratum 3 (Art related Faculties) = $(748 \div 5664) \times 374 \approx 49$

Table 3: The number of International students by related Faculties composed by the researcher from the number by Faculties in the University of Debrecen listed on October 15, 2018. Source: Net6

\begin{tabular}{lcr}
\hline \multicolumn{1}{c}{ Faculties } & Frequency & $\begin{array}{r}\text { Calculated } \\
\text { Sample size }\end{array}$ \\
\hline $\begin{array}{l}\text { Medical and } \\
\text { Health } \\
\text { Related } \\
\text { Faculties }\end{array}$ & 2,971 & 196 \\
\hline $\begin{array}{l}\text { Science } \\
\text { Related } \\
\text { Faculties }\end{array}$ & 1,945 & 129 \\
\hline $\begin{array}{l}\text { Art Related } \\
\text { Faculties }\end{array}$ & 748 & 49 \\
\hline Total & 5,664 & 374 \\
\hline
\end{tabular}




\section{Research Methodology}

The Research Design used for the study was a non-experimental, descriptive, quantitative survey design.

The Research Instrument used was a questionnaire was used developed from the researcher's knowledge and a modified version of the 3 stress questionnaires because different stress factors were examined which are:

1. Student Stress Survey Questionnaire + Template developed by Question Pro: 18 items (Net8).

2. Acculturative Stress Scale for International Students (ASSIS) containing 36-items developed by (SANDHU and ASRABADI, 1994): 36 items

3. Academic Stress Scale developed by BUSARI (2011): 50-items

The modifications made was that only some questions and the Likert format relevant for the study were selected so as not to make the questionnaire bogus and uninteresting

The method of data collection employed were face to face basis, online questionnaire and the Faculty of Health, University of Debrecen neptun system.

The method of data analysis employed were descriptive and inferential statistics. Data collected from this study were coded. The coded data was inspected within Microsoft excel version 2016 to ensure coding accuracy. The data was later transferred into the Statistical Packages for Social Sciences (SPSS) version 26 for analysis. The descriptive statistics (frequency tables, percentages and pie charts) was used to analyse the demographic information of the respondents and the objectives. The inferential statistics
(Simple Linear and multiple Regression) was used to test the hypotheses. Simple linear regression was used to test hypotheses (1-6) and multiple regression was used to test hypothesis 7 at $5 \%$ level of significance.

The ethical principles that guided the study were respect for the person, beneficence, justice, privacy and confidentiality.

\section{Data Presentation and Analysis}

This study examined Stress Factors, Effects, and Management Techniques among International Students at the University of Debrecen, Hungary. The study employed descriptive statistics (frequency tables, percentages, and pie charts) for data analysis. Three hundred and seventy-four (374) copies of questionnaires were administered and all the hundred and seventy-four (374) copies were retrieved, making a 100\% return rate. The results were presented in tables and discussed according to the research objectives.

Table 4 described the socio-demographic characteristics of the respondents. 374 respondents participated in this study out of which $57.2 \%$ were male, $39.8 \%$ were between the ages of 26-35 years, $51.1 \%$ were Christian, $47 \%$ were from Asian continent, 39.0\% were undergraduate students, $52 \%$ were from Medical Related Faculties and 45.2\% got admission through Stipendium Hungaricum. This implies that majority of the respondents were undergraduate students between the ages of 26-35 years under the Stipendium Hungaricum scholarship.

Figure 5 and 6 described the number of inter-national students by nationality (Continents) and related faculties. $52 \%$ of the res- 
Table 4: Demographic Characteristics of the Respondents (n=374). Source: FIELD SURVEY, 2020.

\begin{tabular}{|c|c|c|}
\hline Variables & Frequency & $\begin{array}{r}\text { Percentage } \\
(\%)\end{array}$ \\
\hline \multicolumn{3}{|l|}{ Gender } \\
\hline Males & 214 & 57.2 \\
\hline Females & 160 & 42.8 \\
\hline \multicolumn{3}{|l|}{ Age } \\
\hline $15-24$ years & 131 & 35.0 \\
\hline $25-34$ years & 149 & 39.8 \\
\hline $35-44$ years & 44 & 11.8 \\
\hline 45 years above & 50 & 13.4 \\
\hline \multicolumn{3}{|l|}{ Religion } \\
\hline Christianity & 191 & 51.1 \\
\hline Islam & 82 & 21.9 \\
\hline Others & 101 & 27.0 \\
\hline \multicolumn{3}{|l|}{ Nationality (By Continent) } \\
\hline Europe & 87 & 23 \\
\hline Eurasia & 19 & 5 \\
\hline Asia & 177 & 47 \\
\hline Africa & 79 & 21 \\
\hline North America & 6 & 2 \\
\hline South America & 5 & 2 \\
\hline Australia & 1 & 0 \\
\hline \multicolumn{3}{|l|}{ Educational Level } \\
\hline Undergraduate & 146 & 39.0 \\
\hline Post-graduate M.Sc. & 124 & 33.2 \\
\hline Post-graduate Ph.D. & 104 & 27.8 \\
\hline \multicolumn{3}{|l|}{ Faculty } \\
\hline Medical Related Faculties & 196 & 52 \\
\hline Science Related Faculties & 129 & 35 \\
\hline Art Related Faculties & 49 & 13 \\
\hline \multicolumn{3}{|l|}{ Sponsorship Type } \\
\hline Stipendium Hungaricum & 169 & 45.2 \\
\hline Scholarship for Christian & 92 & \\
\hline Young People (SCYP) & 92 & 24.6 \\
\hline Self-Sponsorship & 82 & 21.9 \\
\hline Others & 31 & 8.3 \\
\hline Total & 374 & 100 \\
\hline
\end{tabular}

pondents are from medical and health related faculties, $35 \%$ of them are from Science related faculties and $13 \%$ of them are from related faculties. $23 \%, 5 \%, 47 \%, 21 \%, 2 \%, 2 \%$ and $0 \%$ are from Europe, Asia, Eurasia, Africa, North America, South America and Australia Continent respectively.
Figure 5: Number of International students by Nationality (Continents). Source: FIELD SURVEY, 2020.

\section{Frequency}

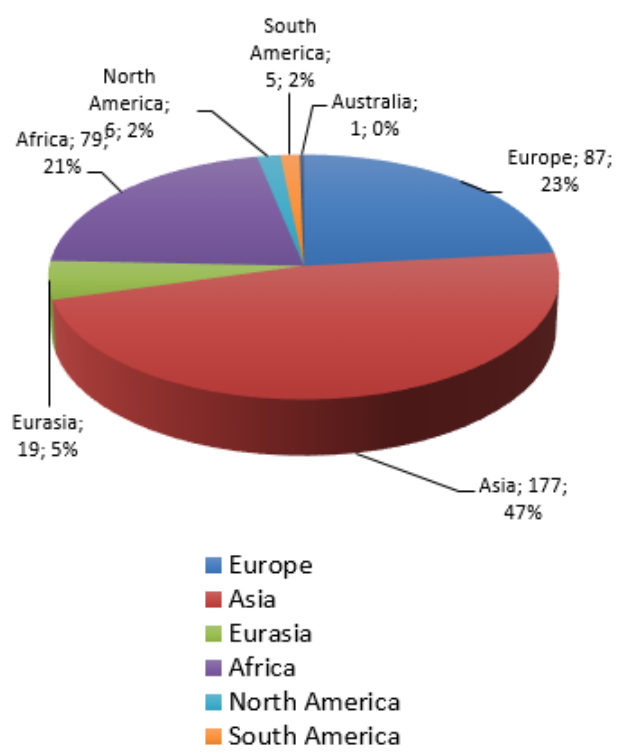

Figure 6: Number of International students by Related Faculties. Source: FIELD SURVEY, 2020

\section{Art \\ Related \\ FREQUENCY}

Faculties

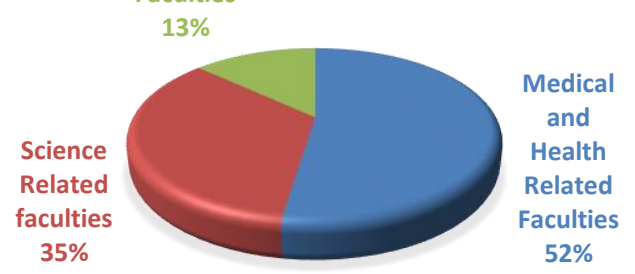

Tables 5-11 summarize descriptive statistics of the results. 
Table 5: Contributing Factors/Causes of Stress among International Students in Hungary. Source: FIELD SURVEY, 2020

\begin{tabular}{|c|c|c|c|c|c|c|}
\hline $\mathrm{S} / \mathrm{n}$ & Statement & NS & SS & MS & HS & ES \\
\hline 1 & $\begin{array}{l}\text { Personal factor is one of the } \\
\text { causes of tress among } \\
\text { international students in Hungary. }\end{array}$ & $\begin{array}{r}26 \\
(7.3 \%)\end{array}$ & $\begin{array}{r}30 \\
(3.4 \%)\end{array}$ & $\begin{array}{r}40 \\
(11.2 \%)\end{array}$ & $\begin{array}{r}116 \\
(32.6 \%)\end{array}$ & $\begin{array}{r}162 \\
(45.5 \%)\end{array}$ \\
\hline 2. & $\begin{array}{l}\text { Academic factor is one of the } \\
\text { causes of stress among } \\
\text { international students in Hungary. }\end{array}$ & $\begin{array}{r}70 \\
(19.7 \%)\end{array}$ & $\begin{array}{r}46 \\
(12.9 \%)\end{array}$ & $\begin{array}{r}74 \\
(59.7 \%)\end{array}$ & $\begin{array}{r}146 \\
(41.0 \%)\end{array}$ & $\begin{array}{r}38 \\
(5.6 \%)\end{array}$ \\
\hline 3. & $\begin{array}{l}\text { Psychological/mental health is } \\
\text { one of the causes of stress among } \\
\text { international students in Hungary. }\end{array}$ & $\begin{array}{r}44 \\
(12.4 \%)\end{array}$ & $\begin{array}{r}34 \\
(4.5 \%)\end{array}$ & $\begin{array}{r}164 \\
(46.1 \%)\end{array}$ & $\begin{array}{r}96 \\
(27.0 \%)\end{array}$ & $\begin{array}{r}36 \\
(10.1 \%)\end{array}$ \\
\hline 4. & $\begin{array}{l}\text { Environmental factor is one of the } \\
\text { causes of stress among } \\
\text { international students in Hungary. }\end{array}$ & $\begin{array}{r}86 \\
(24.2 \%)\end{array}$ & $\begin{array}{r}158 \\
(44.4 \%)\end{array}$ & $\begin{array}{r}50 \\
(14.0 \%)\end{array}$ & $\begin{array}{r}44 \\
(12.4 \%)\end{array}$ & $\begin{array}{r}36 \\
(5.1 \%)\end{array}$ \\
\hline
\end{tabular}

Table 6: Effects/Consequences of Stress on the Physical life of International Students in the University of Debrecen, Hungary. Source: FIELD SURVEY, 2020

\begin{tabular}{|c|c|c|c|}
\hline $\mathrm{S} / \mathrm{n}$ & Statement & YES & NO \\
\hline 1 & Fatigue or Tiredness that does not improve with sleep & $262(48.0 \%)$ & $112(31.6 \%)$ \\
\hline 2. & Tough Breathing & $234(39.9 \%)$ & $140(44.4 \%)$ \\
\hline 3. & Low energy levels & $194(54.5 \%)$ & $180(22.5 \%)$ \\
\hline 4. & Headaches & $216(21.3 \%)$ & $158(44.4 \%)$ \\
\hline 5. & Stomach upset/aches, Nausea and Diarrhoea or Constipation & $209(32.6 \%)$ & $162(45.5 \%)$ \\
\hline 6. & Insomnia & $228(59.7 \%)$ & $146(41.0 \%)$ \\
\hline 7. & Chest pain & $96(27.0 \%)$ & $164(46.1 \%)$ \\
\hline 8. & Frequent colds & $216(24.2 \%)$ & $158(44.4 \%)$ \\
\hline 9. & Shaking or sweating hands & $246(20.8 \%)$ & $128(36.0 \%)$ \\
\hline 10. & Increased heart rate and respirations & $262(48.0 \%)$ & $112(31.6 \%)$ \\
\hline 11. & Increased blood pressure & $212(39.9 \%)$ & $158(44.4 \%)$ \\
\hline 12. & Muscle Tension, soreness/aches or stiffness & $250(43.8 \%)$ & $124(36.5 \%)$ \\
\hline 12. & Increased or decreased appetite which may be accompanied by weight loss or gain & $262(48.0 \%)$ & $112(31.6 \%)$ \\
\hline 13. & Sweating or chills & $216(39.9 \%)$ & $158(44.4 \%)$ \\
\hline 14. & Tremors or muscle twitching & $262(48.0 \%)$ & $112(31.6 \%)$ \\
\hline 15. & Muffled hearing & $234(39.9 \%)$ & $140(44.4 \%)$ \\
\hline 16. & Tunnel vision & $194(54.5 \%)$ & $180(22.5 \%)$ \\
\hline 17. & Feeling uncoordinated & $216(21.3 \%)$ & $158(44.4 \%)$ \\
\hline 18. & Skin breakouts (hives, eczema) & $209(32.6 \%)$ & $162(45.5 \%)$ \\
\hline 19. & Light sensitive vision & $228(59.7 \%)$ & $146(41.0 \%)$ \\
\hline 20. & Lower back pain/ backaches & $96(27.0 \%)$ & $164(46.1 \%)$ \\
\hline 21. & Feeling a "lump in the throat" & $216(24.2 \%)$ & $158(44.4 \%)$ \\
\hline 22. & Easily startled & $246(20.8 \%)$ & $128(36.0 \%)$ \\
\hline 23. & Menstrual cycle changes & $262(48.0 \%)$ & $112(31.6 \%)$ \\
\hline 24. & Change In sexual desire or response/ loss of sex drive & $212(39.9 \%)$ & $158(44.4 \%)$ \\
\hline 25. & Decreased resistance to colds, flu, infections & $250(43.8 \%)$ & $124(36.5 \%)$ \\
\hline 26. & Flare up of allergies, asthma, or arthritis & $262(48.0 \%)$ & $112(31.6 \%)$ \\
\hline 27. & Hair loss & $216(39.9 \%)$ & $158(44.4 \%)$ \\
\hline
\end{tabular}


Table 7: Effects/Consequences of Stress on the Psychological/ Mental Health of International Students in the University of Debrecen, Hungary. Source: FIELD SURVEY, 2020

\begin{tabular}{|c|c|c|c|}
\hline $\mathrm{S} / \mathrm{n}$ & Statement & YES & NO \\
\hline 1 & Sadness, moodiness, grief or depression & $246(20.8 \%)$ & $128(36.0 \%)$ \\
\hline 2. & Anxiety or fear & $262(48.0 \%)$ & $112(31.6 \%)$ \\
\hline 3. & Denial & $212(39.9 \%)$ & $158(44.4 \%)$ \\
\hline 4. & Personality changes and mood swings & $250(43.8 \%)$ & $124(36.5 \%)$ \\
\hline 5. & Feeling heroic, euphoric or invulnerable & $262(48.0 \%)$ & $112(31.6 \%)$ \\
\hline 6. & Worry about safety of self or others & $216(39.9 \%)$ & $158(44.4 \%)$ \\
\hline 7. & Restlessness & $262(48.0 \%)$ & $112(31.6 \%)$ \\
\hline 8. & Vivid or distressing dreams & $234(39.9 \%)$ & $140(44.4 \%)$ \\
\hline 9. & Guilt & $194(54.5 \%)$ & $180(22.5 \%)$ \\
\hline 10. & Feeling overwhelmed, helpless or hopeless & $216(21.3 \%)$ & $158(44.4 \%)$ \\
\hline 11. & Feeling isolated, lost, lonely or abandoned & $209(32.6 \%)$ & $162(45.5 \%)$ \\
\hline 12. & Apathy & $228(59.7 \%)$ & $146(41.0 \%)$ \\
\hline 12. & Over-identification with survivors & $96(27.0 \%)$ & $164(46.1 \%)$ \\
\hline 13. & Feeling misunderstood or unappreciated & $216(24.2 \%)$ & $158(44.4 \%)$ \\
\hline
\end{tabular}

Table 8: Effects/Consequences of Stress on the Behavioural Life of International Students in the University of Debrecen, Hungary. Source: FIELD SURVEY, 2020

\begin{tabular}{|c|c|c|c|}
\hline $\mathrm{S} / \mathrm{n}$ & Statement & YES & NO \\
\hline 1 & Change in activity levels & $96(27.0 \%)$ & $164(46.1 \%)$ \\
\hline 2. & Decreased efficiency and effectiveness & $216(24.2 \%)$ & $158(44.4 \%)$ \\
\hline 3. & Difficulty communicating & $246(20.8 \%)$ & $128(36.0 \%)$ \\
\hline 4. & Increased sense of humour/gallows humour & $262(48.0 \%)$ & $112(31.6 \%)$ \\
\hline 5. & Irritability, outbursts of anger, frequent arguments, hostile or frustrated & $212(39.9 \%)$ & $158(44.4 \%)$ \\
\hline 6. & Isolating or withdrawing yourself from others & $250(43.8 \%)$ & $124(36.5 \%)$ \\
\hline 7. & Overreacting to problems & $262(48.0 \%)$ & $112(31.6 \%)$ \\
\hline 8. & Overdoing activities & $216(39.9 \%)$ & $158(44.4 \%)$ \\
\hline 9. & Picking fights with others & $262(48.0 \%)$ & $112(31.6 \%)$ \\
\hline 10. & Teeth grinding and jaw clenching & $234(39.9 \%)$ & $140(44.4 \%)$ \\
\hline 11. & Nervous habits (e.g. nail biting) & $194(54.5 \%)$ & $180(22.5 \%)$ \\
\hline 12. & Neglecting duties & $216(21.3 \%)$ & $158(44.4 \%)$ \\
\hline 12. & Inability to rest, relax or let down & $209(32.6 \%)$ & $162(45.5 \%)$ \\
\hline 13. & Change in eating habits (eating more or less) & $228(59.7 \%)$ & $146(41.0 \%)$ \\
\hline 14. & Change in sleep patterns (sleeping too much or too little) & $96(27.0 \%)$ & $164(46.1 \%)$ \\
\hline 15. & Change in activity performance & $216(24.2 \%)$ & $158(44.4 \%)$ \\
\hline 16. & Periods of crying & $246(20.8 \%)$ & $128(36.0 \%)$ \\
\hline 17. & Increased use of tobacco, alcohol, drugs, sugar or caffeine & $262(48.0 \%)$ & $112(31.6 \%)$ \\
\hline 18. & Hyper-vigilance about safety of the surrounding environment & $212(39.9 \%)$ & $158(44.4 \%)$ \\
\hline 19. & Avoidance of activities or places that trigger memories & $250(43.8 \%)$ & $124(36.5 \%)$ \\
\hline 20. & Accident prone & $262(48.0 \%)$ & $112(31.6 \%)$ \\
\hline
\end{tabular}


Table 9: Effects/Consequences of Stress on the Cognitive Life of International Students in the University of Debrecen, Hungary. Source: FIELD SURVEY, 2020

\begin{tabular}{llrc}
\hline $\mathbf{S} / \mathbf{n}$ & Statement & YES & NO \\
\hline 1 & Memory problems/forgetfulness & $96(27.0 \%)$ & $\mathbf{1 6 4}(\mathbf{4 6 . 1 \% )}$ \\
2. & Disorientation & $216(24.2 \%)$ & $\mathbf{1 5 8}(\mathbf{4 4 . 4 \% )}$ \\
3. & Confusion & $246(20.8 \%)$ & $\mathbf{1 2 8}(\mathbf{3 6 . 0 \% )}$ \\
4. & Slowness in thinking clearly, analysing, or comprehending & $\mathbf{2 6 2 ( 4 8 . 0 \% )}$ & $112(31.6 \%)$ \\
5. & Indecisiveness, difficulty calculating or setting priorities & $212(39.9 \%)$ & $\mathbf{1 5 8}(\mathbf{4 4 . 4 \% )}$ \\
6. & Difficulty Concentrating or learning & $\mathbf{2 5 0 ( 4 3 . 8 \% )}$ & $124(36.5 \%)$ \\
7. & Limited attention span & $\mathbf{2 6 2 ( 4 8 . 0 \% )}$ & $112(31.6 \%)$ \\
8. & Poor judgement & $216(39.9 \%)$ & $\mathbf{1 5 8}(\mathbf{4 4 . 4 \% )}$ \\
9. & Anxious or racing thoughts & $\mathbf{2 6 2 ( 4 8 . 0 \% )}$ & $112(31.6 \%)$ \\
10. & Constant worrying & $234(39.9 \%)$ & $\mathbf{1 4 0 ( 4 4 . 4 \% )}$ \\
11. & Loss of objectivity & $194(54.5 \%)$ & $180(22.5 \%)$ \\
12. & Fearful anticipation & $216(21.3 \%)$ & $158(44.4 \%)$ \\
13. & Seeing only the negative & $209(32.6 \%)$ & $\mathbf{1 6 2}(\mathbf{4 5 . 5 \% )}$ \\
14. & Inability to stop thinking about a disaster or an incident & $216(39.9 \%)$ & $\mathbf{1 5 8 ( 4 4 . 4 \% )}$ \\
\hline
\end{tabular}

Table 10: Effects/Consequences of Stress on the Social Life of International Students in the University of Debrecen, Hungary. Source: FIELD SURVEY, 2020

\begin{tabular}{lllc}
\hline S/n & Statement & YES & NO \\
\hline 1 & Withdrawing or isolating from people & $212(39.9 \%)$ & $\mathbf{1 5 8}(\mathbf{4 4 . 4 \% )}$ \\
2. & Difficulty listening & $\mathbf{2 5 0 ( 4 3 . 8 \% )}$ & $124(36.5 \%)$ \\
3. & Difficulty sharing ideas & $\mathbf{2 6 2 ( 4 8 . 0 \% )}$ & $112(31.6 \%)$ \\
4. & Difficulty engaging in mutual problem solving & $216(39.9 \%)$ & $\mathbf{1 5 8 ( 4 4 . 4 \% )}$ \\
5. & Blaming & $\mathbf{2 6 2 ( 4 8 . 0 \% )}$ & $112(31.6 \%)$ \\
6. & Criticizing & $234(39.9 \%)$ & $\mathbf{1 4 0 ( 4 4 . 4 \% )}$ \\
7. & Intolerance of group process & $194(54.5 \%)$ & $180(22.5 \%)$ \\
8. & Difficulty in giving or accepting support or help & $216(21.3 \%)$ & $158(44.4 \%)$ \\
9. & Impatient with or disrespectful to others & $209(32.6 \%)$ & $\mathbf{1 6 2 ( 4 5 . 5 \% )}$ \\
\hline
\end{tabular}

Table 11: Stress Management Techniques/Coping Mechanisms. Source: FIELD SURVEY, 2020

\begin{tabular}{llcc}
\hline S/n & Statement & YES & NO \\
\hline 1 & Physical techniques & $\mathbf{2 6 2 ( 4 8 . 0 \% )}$ & $112(31.6 \%)$ \\
2. & Cognitive techniques & $234(39.9 \%)$ & $\mathbf{1 4 0}(\mathbf{4 4 . 4 \% )}$ \\
3. & Environmental techniques & $194(54.5 \%)$ & $180(22.5 \%)$ \\
4. & Spiritual/Religious techniques & $216(21.3 \%)$ & $158(44.4 \%)$ \\
\hline
\end{tabular}

\section{Test of Hypotheses}

Hypothesis 1: Stress has no significant effect on the personal life of international students.

Table 12 shows a significant effect of stress on the personal life of international students. This is because the P-value (0.000) of the
ANOVA is less than the alpha value $(\alpha=0.05)$. Hence, the null hypothesis which states that stress has no significant effect on the personal life of students is hereby rejected at 0.05 level of significance. This implies that there was a significant effect of stress on the personal life 
of international students $(\mathrm{P}<\alpha)$. The $\mathrm{R}^{2}=$ $68 \%$ indicates that the model is suitable for explaining the effect of stress on the personal life of international students.

Table 12: Summary of Simple Linear Regression Analysis on the effect of Stress on the Person Life of International Students. Source: FIELD SURVEY, 2020

\begin{tabular}{lrrrr}
\hline \multicolumn{1}{c}{ Variable } & \multicolumn{1}{c}{ B } & S. Error & t-value & P-value \\
\hline Personal Life (PL) & -0.284 & 0.053 & -5.385 & 0.000 \\
Constant & 0.132 & .057 & 2.330 & 0.021 \\
F-value $=14.425$ & & & & 0.000 \\
$\mathrm{R}^{2}=0.681$ & & & &
\end{tabular}

$\mathrm{R}^{2}=0.681$

Dependent variable: Personal Life (PL)

Independent variables: Stress (STRS)

$\mathrm{S}=$ Significant

The coefficient of Personal Life is negative and significantly related to stress at $5 \%$. This implies that stress has negative effect on the personal life of students. This negative effect may be as a result of accommodation dissatisfaction, adjusting to new foods/poor eating habits, combining jobs with studies, health problems, lack of self-confidence and lack of self-discipline.

Hypothesis 2: Stress has no significant effect on the academic life of International students.

Table 13 shows a significant effect of stress on the academic life of international students. This is because the P-value (0.001) of the ANOVA is less than the alpha value $(\alpha=0.05)$. Hence, the null hypothesis which states that Stress has no significant effect on the academic life of students is hereby rejected at 0.05 level of significance. This means that there was a significant effect of stress on the academic life of international students $(\mathrm{P}<\alpha)$. The $\mathrm{R}^{2}=82 \%$ indicates that the model is suitable for explaining the effect of stress on the academic life of international students.

The coefficient of Academic Life is negative and significantly related to stress at 5\%. This means that stress has negative effect on the academic life of international students. This may be as a result of examination tension, excessive course work or workload, competition with other students, many hours of lectures or studies, procrastination, deadline pressure, low grade, loneliness/ lacking friends and unfamiliar teaching methods.

Table 13: Summary of Simple Linear Regression Analysis on the effect of Stress on the Academic Life of International Students. Source: FIELD SURVEY, 2020

\begin{tabular}{lcccc}
\hline \multicolumn{1}{c}{ Variable } & B & S. Error & t-value & P-value \\
\hline Academic Life (ACAML) & -0.253 & 0.067 & -3.792 & 0.000 \\
Constant & 1.782 & 0.473 & 3.770 & 0.000 \\
F-value $=4.127$ & & & & 0.001 \\
$\mathrm{R}^{2}=0.815$ & & & \\
Dependent variable: Academic Life (ACAML) & & \\
Independent variables: Stress (STRS) & & \\
S = Significant
\end{tabular}

Hypothesis 3: Stress has no significant effect on the psychological life of international students.

Table 14 shows a significant effect of stress on the psychological life of international students. This is because the P-value (0.000) of the ANOVA is less than the alpha value $(\alpha=0.05)$. Hence, the null hypothesis which states that stress has no significant effect on the psychological life of international students is hereby rejected at 0.05 level of significance. 
This implies that there was a significant effect of stress on the psychological life of students $(\mathrm{P}<\alpha)$. The $\mathrm{R}^{2}=72 \%$ indicates that the model is suitable for explaining the effect of stress on the psychological life of international students.

Table 14: summary of Simple Linear Regression Analysis on the effect of Stress on the Psychological Life of International Students the University of Debrecen, Hungary. Source: FIELD SURVEY, 2020

\begin{tabular}{lrrrr}
\hline \multicolumn{1}{c}{ Variable } & B & S. Error & t-value & P-value \\
\hline Psychological (PSYCHL) & -1.798 & 0.420 & -4.282 & 0.000 \\
Constant & 0.302 & 0.055 & 5.518 & 0.000 \\
F-value $=13.521$ & & & & 0.000 \\
$\mathrm{R}^{2}=0.715$ & & & \\
\hline $\begin{array}{l}\text { Dependent variable: Psychological Life (PSYCHL) } \\
\text { Independent variables: Stress (STRS) }\end{array}$ & & & \\
\end{tabular}

The coefficient of Psychological Life is negative and significantly related to stress at $5 \%$. This means that stress has negative effect on the psychological life of international students. This may be as a result of language barriers, unrealistic expectations, illness, home crises and future worries.

Hypothesis 4: Stress has no significant effect on the behavioral life of international students.

Table 15 shows a significant effect of stress on the behavioral life of international students. This is because the P-value (0.000) of the ANOVA is less than the alpha value $(\alpha=$ $0.05)$. Hence, the null hypothesis which states that stress has no significant effect on the behavioral life of international students is hereby rejected at 0.05 level of significance.
This means that there was a significant effect of stress on the behavioral life of students $(\mathrm{P}<$ $\alpha$ ). The $\mathrm{R}^{2}=79 \%$ indicates that the model is suitable for explaining the effect of stress on the behavioral life of international students.

Table 15: Summary of Simple Linear Regression Analysis on the effect of Stress on the Behavioral Life of International Students the University of Debrecen, Hungary. Source: FIELD SURVEY, 2020

\begin{tabular}{lcccc}
\hline \multicolumn{1}{c}{ Variable } & B & S. Error & t-value & P-value \\
\hline Behavioral Life (BEHAL) & -2.430 & 0.435 & -5.586 & 0.000 \\
Constant & 0.416 & 0.660 & 0.630 & 0.529 \\
F-value $=27.734$ & & & & 0.000 \\
$\mathrm{R}^{2}=0.791$ & & & \\
\hline $\begin{array}{l}\text { Dependent variable: Behavioral Life (BEHAL) } \\
\text { Independent variables: Stress (STRS) }\end{array}$ & & & \\
\end{tabular}

The coefficient of Behavioral Life is negative and significantly related to stress at $5 \%$. This means that stress has negative effect on the behavioral life of international students in the University of Debrecen, Hungary. This may be as a result of the fact that stress causes loss of memory and depression

Hypothesis 5: Stress has no significant effect on the cognitive life of international students.

Table 16 shows a significant effect of stress on the cognitive life of international students. This is because the P-value (0.001) of the ANOVA is less than the alpha value $(\alpha=0.05)$. The null hypothesis which states that stress has no significant effect on the cognitive life of students is hereby rejected at 0.05 level of significance. Hence, there was a significant effect of stress on the cognitive life of 
international students $(\mathrm{P}<\alpha)$. The $\mathrm{R}^{2}=60 \%$ indicates that the model is suitable for explaining the effect of stress on the cognitive life of international students.

Table 16: Summary of Simple Linear Regression Analysis on the effect of Stress on the Cognitive Life of International Students the University of Debrecen, Hungary. Source: FIELD SURVEY, 2020

\begin{tabular}{lcccc}
\hline \multicolumn{1}{c}{ Variable } & B & S. Error & t-value & P-value \\
\hline Cognitive Life (COGL) & -2.378 & 0.627 & -3.792 & 0.002 \\
Constant & 1.114 & 0.543 & 2.050 & 0.052 \\
F-value $=7.393$ & & & & 0.001 \\
$\mathrm{R}^{2}=0.602$ & & & \\
$\begin{array}{l}\text { Dependent variable: Cognitive Life (COGL) } \\
\text { Independent variables: Stress (STRS) }\end{array}$ & & & \\
\end{tabular}

The coefficient of Cognitive Life is negative and significantly related to stress at 5\%. This means that stress has negative effect on the cognitive life of international students. This is as a result of the fact that stress fact the mental state of students.

Hypothesis 6: Stress has no significant effect on the social life of international students.

Table 17 shows a significant effect of stress on the social life of students. This is because the P-value (0.000) of the ANOVA is less than the alpha value $(\alpha=0.05)$. The null hypothesis which states that stress has no significant effect on the social life of students is hereby rejected at 0.05 level of significance. Hence, there was a significant effect of stress on the social life of students $(\mathrm{P}<\alpha)$. The $\mathrm{R}^{2}=77 \%$ indicates that the model is suitable for explaining the effect of stress on the social life of international students. The coefficient of Social Life is negative and significantly related to stress at $5 \%$. This means that stress has negative effect on the social life of international students. This may be as a result of language barriers and new environment.

Table 17: Summary of Simple Linear Regression Analysis on the effect of Stress on the Social Life of International Students. Source: FIELD SURVEY, 2020

\begin{tabular}{lcccc}
\hline \multicolumn{1}{c}{ Variable } & B & S. Error & t-value & P-value \\
\hline Social life (SOCL) & -0.180 & 0.132 & -1.369 & 0.185 \\
Constant & 0.669 & 0.399 & & \\
F-value $=24.820$ & & & & 0.000 \\
$\mathrm{R}^{2}=0.772$ & & & & \\
$\begin{array}{l}\text { Dependent variable: Social life (SOCL) } \\
\text { Independent variables: Stress (STRS) }\end{array}$ & & & \\
\hline
\end{tabular}

Hypothesis 7: Stress management techniques employed by students have no significant effect on stress management among international students.

Table 18 shows a significant effect of stress management techniques employed by international students on stress management. This is because the P-value (0.000) of the ANOVA is less than the alpha value $(\alpha=0.05)$. The null hypothesis which states that stress management techniques employed by students have no significant effect on stress management among students is hereby rejected at 0.05 level of significance. Hence, stress management techniques employed by students have significant effect on stress management among students $(\mathrm{P}<\alpha)$. The $\mathrm{R} 2=76 \%$ indicates that the model is suitable for explaining the effect of stress management techniques employed by international students on stress management. 
Table 18: Summary of Multiple Linear Regression Analysis on the effect of Stress Management Techniques Employed by Students on Stress Management among International Student. Source: FIELD SURVEY, 2020

\begin{tabular}{lcccr}
\hline \multicolumn{1}{c}{ Variable } & B & S. Error & t-value & P-value \\
\hline $\begin{array}{l}\text { Physical Techniques } \\
\text { (PHYT) }\end{array}$ & -2.378 & 0.627 & -3.792 & 0.002 \\
Cognitive & & & & \\
Techniques (COGT) & & & & \\
Environmental & 0.552 & 0.165 & 3.336 & 0.003 \\
Techniques (ENVT) & & 0.143 & 2.826 & 0.010 \\
$\begin{array}{l}\text { Spiritual/Religious } \\
\text { Techniques (SPRT) }\end{array}$ & 0.180 & 0.132 & 1.369 & 0.185 \\
Constant & & & & \\
F-value $=24.820$ & 0.669 & 0.399 & & \\
R $2=0.761$ & & & & \\
\hline
\end{tabular}

The coefficient of Physical Techniques is negative and significantly related to stress management at 5\%. This implies that physical technique has negative effect on stress management among students. This negative effect means physical technique is not effective for managing stress among international students.

The coefficient of Cognitive Techniques is positive and significantly related to stress management at $5 \%$. This implies that cognitive technique has positive effect on stress management among students. This positive effect means that cognitive technique is effective for managing stress among international students.

The coefficient of Environmental Techniques is positive and significantly related to stress management at $5 \%$. This implies that environment technique has positive effect on stress management among students. This positive effect means that environment technique is effective for managing stress among international students in the University of Debrecen, Hungary.

The coefficient of Spiritual/Religious Techniques is positive and significantly related to stress management at 5\%. This implies that spiritual/religious technique has positive effect on stress management among students. This positive effect means that spiritual/religious technique is effective for managing stress among international students.

\section{Summary of Findings}

The contributing factors/causes of stress among international students were personal factors, academic factors, psychological/mental health and environmental factors were.

The effects/consequences of stress on the physical life of international students were fatigue or tiredness that does not improve with sleep, tough breathing, low energy levels, headaches, stomach upset/aches, nausea and diarrhea or constipation, insomnia, chest pain, frequent colds, shaking or sweating hands, increased heart rate and respirations, increased blood pressure, muscle tension, soreness/aches or stiffness, increased or decreased appetite which may be accompanied by weight loss or gain, increased or decreased appetite which may be accompanied by weight loss or gain, sweating or chills, tremors or muscle twitching, muffled hearing, tunnel vision, feeling uncoordinated, skin breakouts (hives, eczema), light sensitive vision, lower 
back pain/backaches, feeling a 'lump in the throat', easily startled, menstrual cycle changes, change in sexual desire or response/ loss of sex drive, decreased resistance to colds, flu, infections, flare up of allergies, asthma, or arthritis and hair loss.

The effects/consequences of stress on the psychological/mental health of international students were sadness, moodiness, grief or depression, anxiety or fear, denial, personality changes and mood swings, feeling heroic, euphoric or invulnerable, worry about safety of self or others, restlessness, vivid or distressing dreams, guilt, feeling overwhelmed, helpless or hopeless, feeling isolated, lost, lonely or abandoned, apathy, over-identification with survivors and feeling misunderstood or unappreciated.

The effects/consequences of stress on the behavioral life of international students were change in activity levels, decreased efficiency and effectiveness, difficulty communicating, increased sense of humor/gallows humor, irritability, outbursts of anger, frequent arguments, hostile or frustrated, isolating or withdrawing yourself from others, overreacting to problems, overdoing activities, picking fights with others, teeth grinding and jaw clenching, nervous habits (e.g. nail biting), neglecting duties, inability to rest, relax or let down, change in eating habits (eating more or less), change in sleep patterns (sleeping too much or too little), change in activity performance, periods of crying, increased use of tobacco, alcohol, drugs, sugar or caffeine, hypervigilance about safety of the surrounding environment, avoidance of activities or places that trigger memories and accident prone.
The effects/consequences of stress on the cognitive life of international students were memory problems/forgetfulness, disorientation, confusion, slowness in thinking clearly, analyzing, or comprehending, indecisiveness, difficulty calculating or setting priorities, difficulty concentrating or learning, limited attention span, poor judgement, anxious or racing thoughts, constant worrying, loss of objectivity, fearful anticipation, seeing only the negative and inability to stop thinking about a disaster or an incident.

The effects/consequences of stress on the social life of international students were withdrawing or isolating from people, difficulty listening, difficulty sharing ideas, difficulty engaging in mutual problem solving, blaming, criticizing, intolerance of group process, difficulty in giving or accepting support or help and impatient with or disrespectful to others.

The stress management techniques/coping mechanisms used by international students were physical techniques, cognitive techniques, environmental techniques and spiritual/religious techniques.

There was a significant effect of stress on the personal, academic, psychological, behavioral, cognitive, and social life of international students.

Stress management techniques employed by students have a significant effect on the perception of stress among international students.

\section{Conclusion}

Based on the results of this study it can be concluded that international students experi- 
ence different levels of stress which has a devastating effect on them, they have explored several coping strategies, and management is individualized (person-centered) as the technique that might work for one individual might not work for another.

\section{Recommendations}

Based on the results of this study:

1. The government should increase the coverage of health insurance to cover psychological sessions and antipsychotic drugs.

2. Stress management training should be incorporated into the syllabus and taught to students of the universities.

3. Universities, institutions, and other organizations should reinforce modalities to enhance the wellbeing of students and their general feelings of wellness positively.

4. Practical approaches or strategies and attitudes on acculturation should be adopted by institutions.

5. Person-centered approach should be employed in the management of stress as every individual has a unique experience.

Roles of Health Social Workers in stress management are:

1. The departments of social work should educate students on the strategies for self-care that will help prevent exhaustion during the period of their studies which can, in turn, assist them in their preparation towards working with clients that have undergone trauma.

2. The social worker is responsible for providing counseling services through individual or group therapy to survivors of stress. The social worker utilizes his or her knowledge in psychology in providing counseling services to survivors of stress and other psychological interventions in collaboration with a psychologist/psychiatrist.

3. The social worker serves as an advocate for the stress survivors in mobilizing diverse resources to help in combating stress.

4. The social worker provides health education to clients on the contributing factors, effects, and various management techniques of stress

\section{References}

ALHARBIL E.S. and SMITH A.P. (2018).

Review of the literature on stress and wellbeing of international students in English-speaking countries. International education studies, 11. ISSN 1913-9020 EISSN 1913-9039. doi: 10.5539/ies.v11n6p2

ARCH J.J., AYERS C.R., BAKER A., ALMKLOV E., DEAN D.J. and CRASKE M.G. (2013). Randomized clinical trial of adapted mindfulness-based stress reduction versus group cognitive behavioral therapy for heterogeneous anxiety disorders. Behaviour research and therapy, 51. 185-196.

ASMUNDSON G.J., FETZNER M.G., DEBOER L.B., POWERS M.B., OTTO M.W. and SMITS J.A. (2013). Let's get physical: A contemporary review of the anxiolytic effects of exercise for anxiety and its disorders. Depression and anxiety, 30. 362-373.

BALI A. and JAGGI A.S. (2015). Clinical experimental stress studies: Methods and 
assessment. Reviews in the neuroscience, 26. 555-579.

BEITER R., NASH R., MCCRADY, RHOADES D., LINSCOMB M., CLARAHAN M. and SAMMUT S. (2014). The prevalence and correlates of depression, anxiety, and stress in a sample of college students. Journal of affective disorders, 173. 90-96. Procedia- Social and Behavioural Sciences. 200. 460-466.

BROUGHAM R.R., ZAIL C.M., MENDOZA C.M. and MILLER J.R. (2009). Stress, sex differences, and coping strategies among college Students. Current Psychology, 28. 85-97. doi: $10.1007 / \mathrm{s} 12144-$ 009-9047-0

BUSARI A. (2011). Validation of student academic stress scale (SASS). European Journal of Social Sciences. 21. 94-105.

CAVALLO P. and CARPINELL L. (2016).

Perceived stress and bruxism in university students. BMC research notes, 9. 514.

CAN Y. ILES-SMITH, HEATHER, CHALABIANLOO, NIAZ, EKIZ, DENIZ, FERNANDEZ-ALVAREZ, JAVIER, REPETTO, CLAUDIA, RIVA, GIUSEPPE, ERSOY and CEM. (2020). How to relax in stressful situations: A smart stress reduction system. Healthcare. 8. doi: $10.3390 /$ healthcare 8020100 .

CHENG P., LUCERO A., BUUR J. (2016). Pause: Exploring Mindful Touch Interaction on Smartphones. In proceedings of the 20th International academic mindtrek conference. Association for Computing Machinery, 184-191. doi: $\underline{10.1145 / 2994310.2994342}$

CHINAVEHA M., ISHAKB M. and

SALLEH A.M. (2010). Improving Mental Health and Academic Performance through Multiple Stress Management Intervention: Implication for Diverse
Learners. Procedia Social and Behavioral

Sciences, 7. 311-316

CHONG C.S., TSUNAKA M. and CHAN

E.P. (2011). Effects of yoga on stress management in healthy adults: A systematic review. Alternative therapies in bealth and medicine, 17. 32.

COBB, S. (1976). Social support as a moderator of life stress. Psychosomatic medicine, 38(5), 300-314. doi: 10.1097/00006842-197609000-00003

FINK G. (2017). Stress: Concepts, definition and history. Reference Module in Neuroscience and Biobehavioral Psychology, 2017. 1-9. doi: 10.1016/B978-0-12-809324-5.02208-2

GALBRAITH N.D. and BROWN K.E. (2011). Assessing intervention effectiveness for reducing stress in student nurses: quantitative systematic review. Journal of advanced nursing 67(4). 709-721. doi: 10.1111/j.1365-2648.2010. 05549.x

GARZA E. and GUZMAN N. (2015). International student's challenge and adjustment to college. Education research international, 2015. doi: 10.1155/2015/202753.

HARKNESS K.L. and HAYDEN E.P. (2018). The Oxford handbook of Stress and Mental Health. Oxford University Press, Oxford, UK.

HARKNESS K., HAYDEN E.; OLINO T., MENNIES R. and WOJCIESZAK Z. (2020). Personality-Stress Vulnerability Models. In the Oxford Handbook of Stress and Mental Health. Oxford University Press, Oxford, UK.

KENNARD J. (2018). A brief history of the term 'stress'- Health central. Retrieved from: https://www.healthcentral.com/article/7 -ways-parenting-styles-affect-child-anxiety 
KOSHELEVA E.Y., AMARNOR A.J. and CHERNOBILSKY E. (2015). Stress factors among international and domestic students in Russia. Procedia - Social And Behavioral Sciences, 200. 460-466. doi: 10.1016/j.sbspro.2015.08.096

KRONER-HERWIG, BIRGIT and AKHTAR M. (2014). Acculturative stress among international students in context of socio-demographic variables and coping styles. Current Psychology, 33. doi: 10.1007/s12144-015-9303-4.

KSHIRSAGAR R. and SEEMA A. (2016). A conceptual framework on stress among undergraduate students - A literature review. International journal of management, IT and engineering, 6 (8). ISSN: 2249-0558.

NET1: http://oer2go.org/mods/enboundless/www.boundless.com/psychol ogy/textbooks/boundless-psychologytextbook/stress-and-health-psychology$17 /$ coping-with-and-managing-stress89/the-value-of-spirituality-and-faith-inmanaging-stress-342-12877/index.html (Webpage of Boundless Psychology); Visited: 05. 2020.

NET2: https://www.mentalhealth.org.uk/ato-z/s/stress (Webpage of Mental Health Foundation); Visited: 05. 2020.

NET3: https://www.nhs.uk/livewell/exercise/guide-to-tai-chi/ (Webpage of National Health Service); Visited:05. 2020.

NET4:

https://en.wikipedia.org/wiki/Debrecen (Webpage of Wikipedia); Visited: 04. 2020.

NET5:

https://en.wikipedia.org/wiki/Hungary (Webpage of Wikipedia); Visited: 04. 2020.

NET6:

https://www.edu.unideb.hu/page.php?fa cts-and-figures\&id=28 (Webpage of the University of Debrecen); Visited: 04. 2020.

NET7:

https://www.worldatlas.com/webimage/ countrys/europe/hu.htm\#page

(Webpage of the World Atlas); Visited: 04. 2020.

NET8:

https://www.questionpro.com/surveytemplates/student-stress/ (Webpage of the Question Pro); Visited: 04. 2020.

NILANI L., SHANKAR and L. PARK C.L. (2016) Effects of stress on students' physical and mental health and academic success, International Journal of School \& Educational Psychology, 4:1, 5-

9, DOI: $\underline{10.1080 / 21683603.2016 .1130532}$

PASCOE M.C., HETRICK S.E. and PARKER A.G. (2020). The impact of stress on students in secondary school and higher education. International journal of adolescence and youth, 25. 104-

112. doi: $\underline{10.1080 / 02673843.2019 .159682}$ $\underline{3}$

PIERCEALL E.A. and KEIM M.C. (2007)

Stress and coping strategies among community college students. Community college Journal of research and practice, 31 . 703-712. doi: $\underline{10.1080 / 10668920600866579}$

RAJAB A., RAHMAN H.A., PANATIK S.A. and MANSOR N.S. (2014). Acculturative stress among international Students. Journal of economics, business and management, 2. 262-265.

REDDY K. J., MENON K. R., THATTIL A. (2018). Academic Stress and its Sources Among University Students. Journal of Biomedical Pharmacology, 11. Doi: $10.13005 / \mathrm{bpj} / 1404$ 
RICE, V. H. (2018). Theories of stress and its relationship to health. Retrieved from: https://pdfs.semanticscholar.org/8bdd/7 1f8ffa51174d160fd67ef99139b243f6dce.p df? ga=2.138909686.453006669.1588627 271-1714790947.1572988268

RONO K.L.D. (2018). Research article microcredit and its relationship to the growth of small and medium enterprises in Konoin subcounty, Kenya.

International Journal of advanced research, 6 . 961-968 961. Doi: $\underline{\text { 10.21474/IJAR01/6935 }}$

SANDHU D.S. and ASRABADI B.R. (1994). Development of an acculturative stress scale for international students: preliminary findings. Psychological Reports, 75, 435-448. doi: $10.2466 / \mathrm{pr} 0.1994 .75 .1 .435$.

SIMPSON S. (2018). titled "Stress Triggers, the Effects Stress Has on Social, Mental and Physical Behaviour in College Students, and the Coping Mechanisms Used" Integrated Studies, 215. 1-62.

SINCERO S.M. (2012). Psychological Theories of Stress. Retrieved from Explorable.com: https://explorable.com/psychologicaltheories-of-stress

SONG Y. and LINQUIST R. (2015). Effects of mindfulness-based stress reduction on depression, anxiety, stress and mindfulness in Korean nursing students. Nurse Education Today, 35. 86-90.
TURNER-COBB J.M. and Hawken T (2019). Cambridge Handbook of Psychology, Health and Medicine. In: LLEWELLYN C.D., AYERS S., MC MANUS C., M, STANTON N,John WEIMMAN J. Cambridge University Press, Cambridge, United Kingdom

UCHIL H. B. (2017). The effect of stress on students' performance. Stress management professional international Journal, 5. 17-21.

YIKEALO, DAWIT Y. YEMANE B. and IKALI K. (2018). The level of academic and environmental stress among college students: A case in the college of education. Open journal of social sciences. 06. 40-57. doi: $10.4236 /$ jss. 2018.6110 